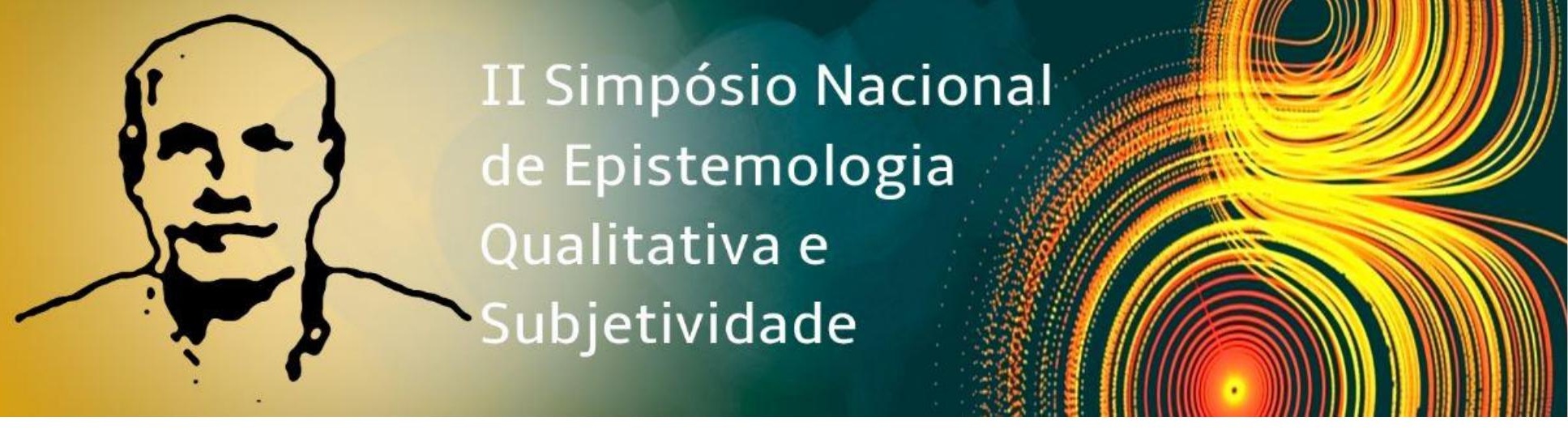

Eixo temático: Aprendizagem e dificuldades de aprendizagem na perspectiva da subjetividade

\title{
Aprendizagem de estudantes que realizam investigação em um clube de ciências
}

Maridalva Costa Nascimento, UFPA, m.sci@ hotmail.com Andrela Garibaldi Loureiro Parente, UFPA, andrelagaribaldi40@gmail.com

\section{Resumo}

Nosso objetivo nesse estudo é investigar a aprendizagem de estudantes em um clube de ciências. Aprendizagem que pode ser concebida desde uma perspectiva reprodutivamemorística até uma perspectiva compreensiva e criativa (GONZÁLEZ REY; MITJÁNS MARTÍNEZ, 2017). Entendemos que aprendizagem não se dá somente no âmbito escolar, mas também em ambientes não formais, como por exemplo, os clubes de ciências (RAMALHO et. al., 2012). Em Castanhal, no nordeste paraense, atuo como professora-monitora em um desses espaços - o qual atende crianças de escolas públicas que cursam o quinto ou sexto ano do ensino fundamental. Para realizar as atividades com os estudantes nos fundamentamos nas sequências de ensino investigativo (CARVALHO, 2013; MALHEIRO, 2016). Nossa concepção de ciência no clube é pós-positivista (DRIVER et. al., 1999), pois neste espaço os estudantes são instigados a expor suas ideias e a propor soluções, cabendo ao professor-monitor fazer "a mediação entre o mundo cotidiano das crianças e o mundo da ciência" (Ibid., p. 39). Reconhecemos a necessidade de incentivar e valorizar à imaginação no ensino e na aprendizagem (EGAN, 2007) e inspirados na Teoria da Subjetividade - o envolvimento afetivo dos estudantes com o que estão a produzir (GONZÁLEZ REY, 2014). Sem esse envolvimento os estudantes não produzem sentidos subjetivos favoráveis à aprendizagem (GONZÁLEZ REY; MITJÁNS MARTÍNEZ, 2017). Assim, propomos, no âmbito da Teoria da Subjetividade, conceber a aprendizagem em ciências como um processo de ordem simbólico-emocional, destacando o papel da imaginação no contexto das práticas investigativas. E, nos perguntamos - "como a imaginação participa na aprendizagem dos estudantes quando realizam investigação em um clube de ciências?"

Palavras chave: Aprendizagem. Imaginação. Ensino investigativo. 


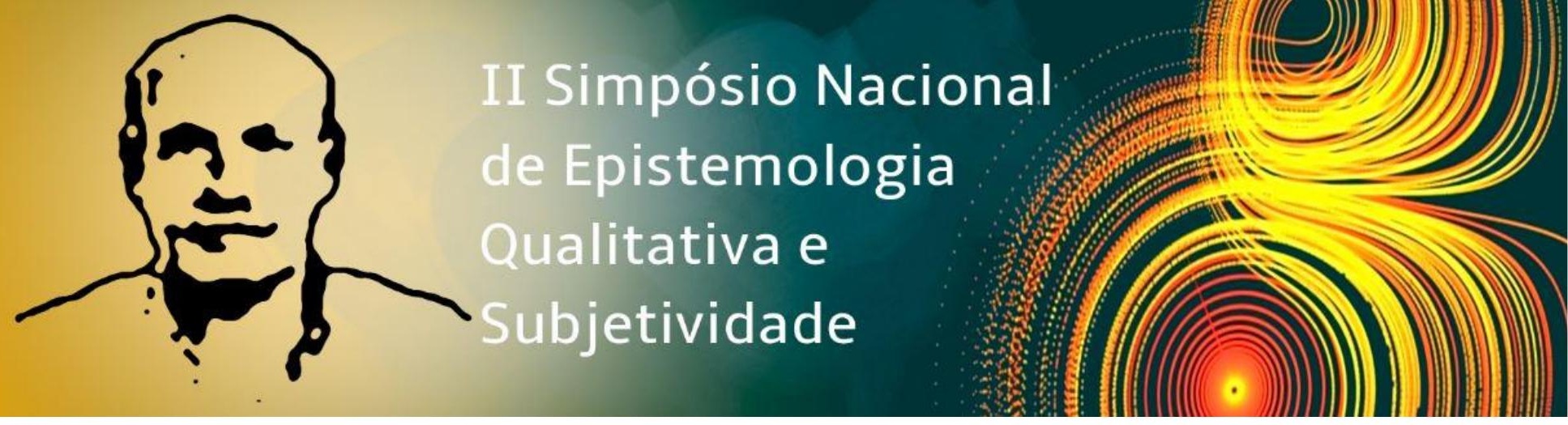

\section{Referências}

CARVAlHO, A. M. P. O Ensino de Ciências e a Proposição de Sequencias de Ensino Investigativas. In: $\quad$ CARVALHO, A. M. P. (Org.). Ensino de Ciências por Investigação: Condições para implementação em sala de aula. São Paulo: Cengage Learning, 2013, p. 1-20.

DRIVER, R.; ASOKO, H.; LEACH, J.; MORTIMER, E. F.; SCOTT, P. Construindo conhecimento científico em sala de aula. Química Nova na Escola. n. 9, p. 31-40, maio1999.

EGAN, K. Por que a imaginação é importante na educação? In: FRITZEN, C; CABRAL, G. S. (Org.). Infância: Imaginação e educação em debate. Campinas, SP: Papirus, 2007.

GONZÁLEZ REY, F. L. A imaginação como produção subjetiva: as ideias e os modelos da produção intelectual. In: MITJÁNS MATÍNEZ, A; ÁLVAREZ, P (Org.). O sujeito que aprende: diálogo entre a psicanálise e o enfoque histórico-cultural. Brasília: Liberlivro, 2014.

MALHEIRO, J. M. S. Atividades experimentais no ensino de ciências: limites e possibilidades. In: ACTIO, Curitiba, v. 1, n. 1, p. 108-127, jul./dez. 2016. Disponível em: https://periodicos.utfpr.edu.br/actio/article/download/4796/3150 Acesso em: 3 maio 2017.

MITJÁNS MARTÍNEZ, A; GONZÁLEZ REY, F. Psicologia, educação e aprendizagem escolar: avançando na contribuição da leitura cultural-histórica. São Paulo: Cortez, 2017.

RAMALHO, P. F. N.; CHAVES, R. K. C.; SANTOS, J.; SERBENA, A. L.; SERRATO, R. V.; REIS, R. A. Clubes de Ciências: educação científica aproximando universidades e escolas públicas no litoral paranaense. Disponível em:

www.nutes.ufrj.br/abrapec/viiienpec/resumos/R1074-1.pdf. Acesso em: 9 jan. 2019. 